\title{
NUTRITIONAL CHANGES IN THE FRUITS OF BOTTLE GOURD DUE TO ARTIFICIAL INOCULATION OF TWO PHYTOPATHOGENIC FUNGI
}

\author{
ARCHITA PRAKASH ${ }^{\text {a1 }}$ AND PREETI PRASAD ${ }^{\mathrm{b}}$ \\ ${ }^{a}$ Department of Botany, B.R.A. Bihar University, Muzaffarpur, Bihar, India \\ ${ }^{\mathrm{b}}$ Professor \& Former Head, Plant Pathology Laboratory. Department of Botany, B.R. Ambedkar Bihar University, Muzaffarpur, Bihar, \\ India
}

\begin{abstract}
In the present study, spore suspension of two different pathogens, Alternaria alternata and Colletotrichum gloeosporioides, isolated from infected fruits of bottle gourd and maintained in the laboratory as pure culture, were separately inoculated in some aged healthy fruits of bottle gourd by pre-sterilized disposable syringe under aseptic condition. Biochemical changes at different periods of incubation, with respect to sugar, protein, ascorbic acid, and amino acids were evaluated, separately for both the pathogens. It was noted that the rate of deterioration of the above component was directly related to the incubation period which was maximum on the $12^{\text {th }}$ day of incubation. There were drastic changes in the total contents of sugar, proteins, ascorbic acid, and amino acid in the infected fruits in comparison to the healthy one. It was further noted that fruits inoculated with Alternaria alternata revealed maximum degradation of all the above components in comparison to the fruits inoculated with Colletotrichum gloeosporioides after similar periods of incubation. Certain amino acids were not detected among the infected fruits on the $12^{\text {th }}$ day of incubation in both cases. Similarly, it was observed that the degradation rate gradually increased along with the increase of the incubation periods.
\end{abstract}

KEYWORDS: Bottle Gourd Fruit, Inoculation, Incubation, Biochemical, Ascorbic Acid, Fungal Pathogen

Bottle gourd (Lagenaria siceraria Molina), of family Cucurbitaceae, is an annual herbaceous climber, which is being cultivated in summer and winter season. This plant produces fruits, which are used as a vegetable when it is immature. The fruit bears several medicinal properties. The entire plant is recognized to be beneficial in an ethnic system of medicine. The fruits are used as a vegetable as well as fresh juice is extracted from the healthy fruits and used for the treatment of different diseases.

The oil extracted from the mature seeds are also used by local people as folk medicines. Different parts of the plants are for the treatment of jaundice, diabetes, piles, ulcer, hypertension, congestive cardiac failure, and skin diseases. The fruit pulp is used as an emetic, sedative, purgative, cooling, etc. The flowers are an antidote to poison. The seed is vermifuge. Leaf juice is widely used for baldness. (Rahman, 2003). The juice is used for the remedy of urinary disorders and diabetes. Juice of bottle gourd and sesame oil rubbed on scalp gives beneficial results in baldness. Different medicinal properties are due to the presence of flavonoids, triterpenes, volatile essential oil, and several other secondary metabolites.

India is the second major producer of fruits and vegetables in the world. It contributes 14 percent of world vegetable production. Vegetables are more prone to spoilage than cereals due to their nature and composition. Spoilage of vegetables is mostly due to fungal and bacterial pathogens. The inoculums for these pathogens are provided by infected host debris lying in the fields, the air, water, etc. The losses in vegetables due to spoilage starting from the growing in fields, storage, transportation, etc. account for 30-36 percent of total yields. The waste generated due to spoilage comes to more than 50 million tons per annum and the loss of farmers is beyond expectation. (Rawat, 2015).

Degradation of nutrition value of vegetables have been reported by different workers such as- Srivastava and Tandon (1966), Gangawane and Datar (1978), Mazumdar and Pathak (1989), Aldesuquy et al., (1992), Agarwal and Agarwal (1982), Hossain et al., (1999), Khilare et al., (2005), Ponmurugan and Baby (2007), Janave (2008), Bhale et al., (2010), Sawant and Gawai (2011), Chatage and Bhale (2012), Ghad Singh and Mandge (2012), Ismail et al., (2012), Rathod and Chavhan (2012), Wagh and Bhale (2012), Srivastva and Pandey (2012), Srivastva and Kumar (2013), Rajmane and Korekar (2014), Embaby and Karkar (2015), Kedarnath et al., (2015), Meena et al., (2016). Keeping these ideas in mind, nutritional changes due to artificial infection by two phytopathogenic fungi at different periods of incubation was evaluated. 


\section{MATERIALS AND METHODS}

\section{Evaluation of Total Sugar Content}

$100 \mathrm{mg}$ of homogenized pulp was taken. It was extracted with $5 \mathrm{ml}$ of $80 \%$ ethanol and centrifuged at 3000 rpm for 10 minutes. Extraction was repeated 3 times with $80 \%$ ethanol and the supernatant was taken in a volumetric flask of $25 \mathrm{ml}$. The final volume of the extract was made to $25 \mathrm{ml}$ with $80 \%$ ethanol. The extract $(0.3 \mathrm{ml})$ was pipetted from the extract taken at different incubation in separate test tubes and then tubes were placed into a boiling water bath for 3-4 minutes to evaporate the ethanol. One $\mathrm{ml}$ sterilized distilled water and $4 \mathrm{ml}$ of $0.2 \%$ anthrone reagent ( $200 \mathrm{mg}$ in $100 \mathrm{ml} \mathrm{H}_{2} \mathrm{So}_{4}$ ) were added in each test tube and placed in ice cold water. Reagent blank was prepared by adding $1 \mathrm{ml}$ of distilled water and $4 \mathrm{ml}$ of anthrone reagent. The intensity of colour was determined at $600 \mathrm{~nm}$ on a spectrophotometer. A standard curve was prepared using 10 $\mathrm{mg}$ glucose per $100 \mathrm{ml}$ distilled water.

\section{Total soluble sugar $(\mathrm{mg} / \mathrm{g})=$ Sample OD $\times$ Standard OD x Dilution factor}

Healthy fruits pulp was used as a control.

Changes in protein content were estimated by using Lowry's et al., (1951) method. The modified Lowry protein measurement was used. The assay was carried out by diluting the extract to $1 \mathrm{ml}$ with $\mathrm{H}_{2} \mathrm{O}$ and adding $0.9 \mathrm{ml}$ of solution A. $(2 \mathrm{~g} / 1$ potassium sodium tartrate and $100 \mathrm{~g} / \mathrm{l}$ sodium carbonate in $0.5 \mathrm{M} \mathrm{NaOH}$ ) before incubation for 10 minutes at $50^{\circ} \mathrm{C}$.

The samples were cooled down at room temperature. To the above, $1 \mathrm{ml}$ of solution $\mathrm{B}(0.2 \mathrm{~g} / \mathrm{l}$ potassium sodium tartrate, and $0.1 \mathrm{~g} / 1$ copper sulphate pentahydrate in $0.1 \mathrm{M} \mathrm{NaOH}$ ) and the tube was left for 10 minutes. Finally, $3 \mathrm{ml}$ of solution $\mathrm{C}$ (Folin reagent in $\mathrm{H}_{2} \mathrm{O}$ $(1: 6 \mathrm{v} / \mathrm{v}))$ was added and incubated for $10 \mathrm{~min}$ at $50^{\circ} \mathrm{C}$. A standard curve was prepared from a known concentration of protein $(0.0625,0.125,0.25,0.5$ and $1 \mathrm{~g} / \mathrm{l})$ the absorbance was taken and thus protein content was determined.

\section{Ascorbic Acid}

$5 \mathrm{~g}$ of tissue from healthy and inoculated fruit after different periods of incubation was taken separately. It was crushed in a pre-sterilized mortar with a pestle, in which 0.4 percent oxalic acid was added at the rate of $4 \mathrm{ml}$ per gram. It was filtered through two layered muslin cloth and the filtrate was centrifuged at $1000 \mathrm{rpm}$ for 20 minutes. The supernatant was taken and the final volume was raised to $25 \mathrm{ml}$ to represent one gram tissue per $5 \mathrm{ml}$ extract.

i. The standard solution of ascorbic acid was prepared by adding $50 \mathrm{mg}$ ascorbic acid to $50 \mathrm{ml}$ of 0.4 percent oxalic acid. The final volume was made $250 \mathrm{ml}$ by adding 0.4 percent oxalic acid to represent $0.2 \mathrm{mg}$ ascorbic acid per $\mathrm{ml}$ of solution.

ii. Indophenols reagent: $150 \mathrm{ml}$ sterilized distilled water was taken in a $200 \mathrm{ml}$ volumetric flask. $50 \mathrm{mg}$ of sodium 2,6-dichlorophenol indophenol was added. The flasks were heated gently over a hot water bath to dissolve the dye. $42 \mathrm{mg}$ of sodium bicarbonate was added to the above solution. The volume was raised to 200 with sterilized distilled water.

Five $\mathrm{ml}$ of standard ascorbic acid solution was taken in a conical flask and titrated against the indophenols dye kept in a burette until the solution became pink and colour persisted for at least 15 seconds.

Now $5 \mathrm{ml}$ of oxalic acid extract was taken and titrated against standardized indophenols dye until the solution became pink and colour persisted for at least 15 seconds.

Calculation of ascorbic acid was done by using the formula:

\section{Ascorbic acid $(\mathrm{mg} / 100 \mathrm{~g}$ tissue $)=1 \times \mathrm{S} \times \mathrm{D} / / \mathrm{A} \times 100 / \mathrm{W}$}

Where,

$1=\mathrm{ml}$ of indophenols reagent was used.

$\mathrm{S}=\mathrm{mg}$ of ascorbic acid reacting with one $\mathrm{ml}$ of indophenols reagent

$\mathrm{D}=$ Vol. of extract in $\mathrm{ml}$

$\mathrm{A}=$ The aliquot titrated in $\mathrm{ml}$

$\mathrm{W}=$ Weight of the sample in $\mathrm{g}$.

\section{RESULTS AND DISCUSSION}

Healthy fruits of bottle gourd having the same age and size were inoculated with the spore suspensors of Alternaria alternata and Colletotrichum gloeosporioides isolated from the infected fruits and maintained as pure culture in the laboratory. Evaluation of percentage loss of sugar, protein and ascorbic acid was done after different periods of incubation. The data obtained have been represented by graphs 1-3. 
Graph 1: Showing percentage of degradation of Ascorbic acid in the infected fruits of bottle gourd by Alternaria alternata \& $C$. gloeosporioides and control, after a different period of incubation

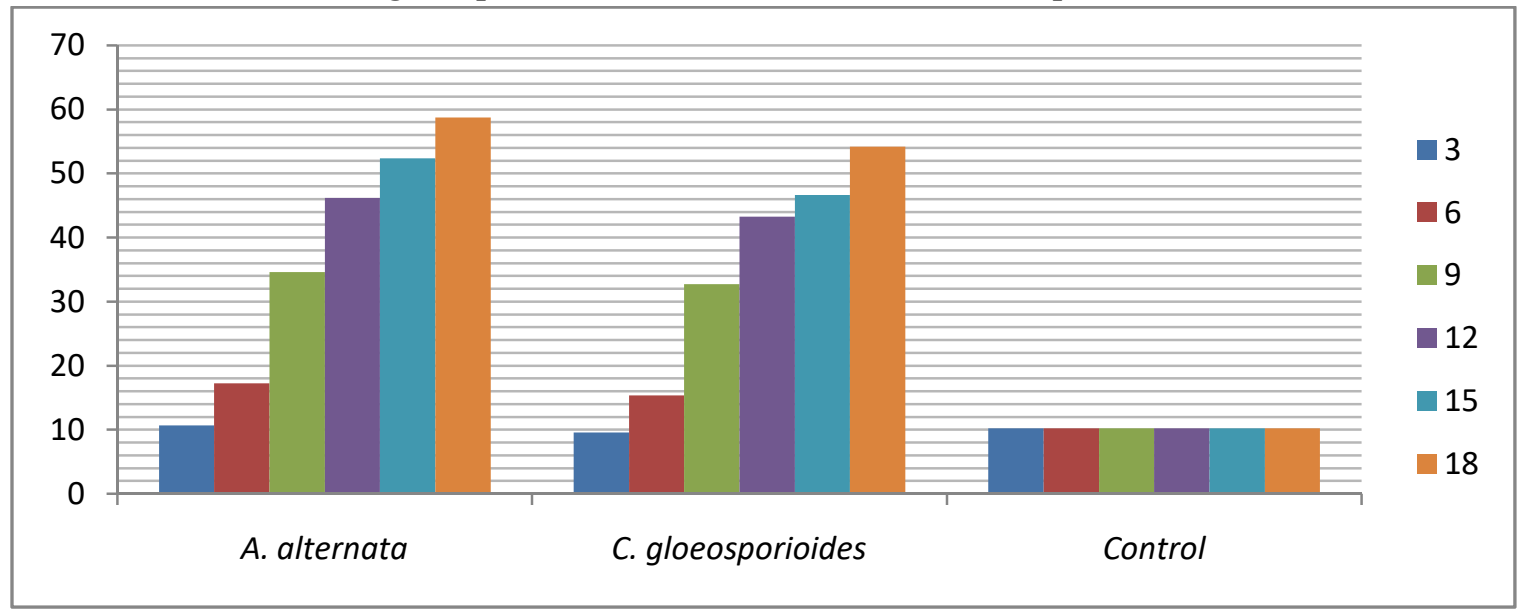

Graph 2: Showing percentage degradation of sugar in the infected fruits of bottle gourd by Alternaria alternata \& $C$. gloeosporioides and control, after a different period of incubation

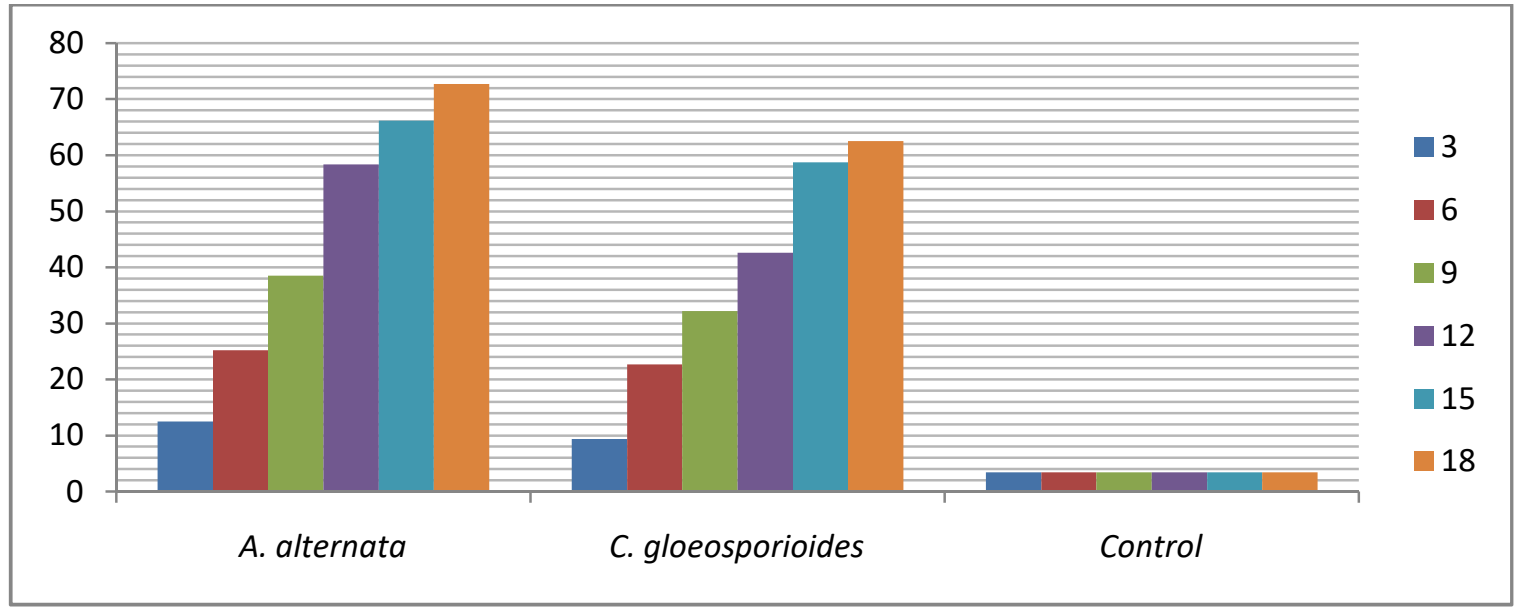

Graph 3: Showing the percentage of degradation of protein content in the infected fruits of bottle gourd by Alternaria alternata \& $C$. gloeosporioides and control, after a different period of incubation

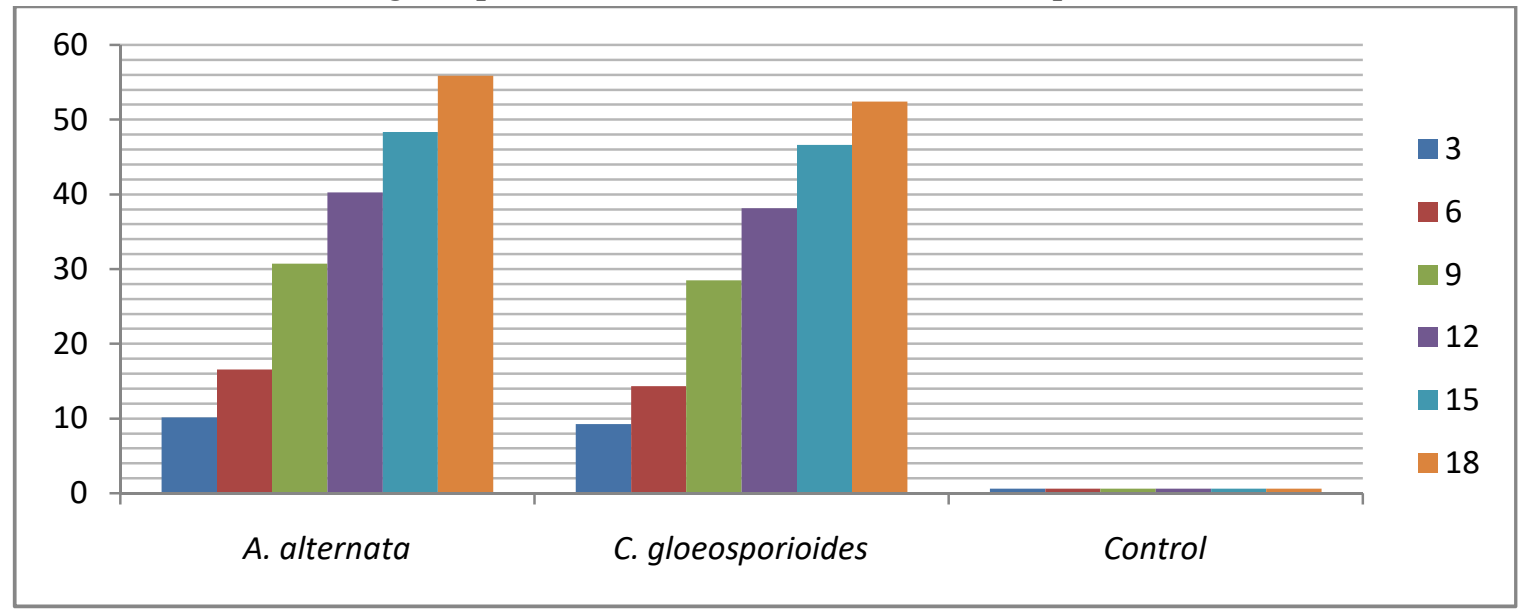


The amount of carbohydrate in healthy fruit of bottle gourd has been calculated to be $3.39 \mathrm{~g} / 100 \mathrm{~g}$ of tissues (Rahman, 2003). From the graph it may be noted that the maximum degradation of carbohydrate (Sugar) $72.68 \%$ among the fruits inoculated with spores of Alternaria alternata was on the $18^{\text {th }}$ day of incubation, followed by $66.72 \%$ on the $15^{\text {th }}$ day of incubation.

A similar period of incubation, fruits inoculated by Colletotrichum gloeosporioides revealed $62.54 \%$ and $58.72 \%$ degradation respectively. On the $3^{\text {rd }}$ day of incubation $12.48 \%$ and $9.38 \%$ were degraded in the case of Alternaria alternata and C. gloeosporioides respectively.

The percentage of degradation of protein content was also evaluated. Here also a maximum of $55.85 \%$ and $52.42 \%$ amount of protein was degraded on the $18^{\text {th }}$ day of incubation among the fruits of bottle gourd which were inoculated with Alternaria alternata and Colletotrichum gloeosporioides respectively. Minimum degradation of protein was found in both the cases on the $3^{\text {rd }}$ day of incubation, which was $10.14 \%$ and $9.26 \%$ respectively. Ascorbic acid which has been reported to be $10.2 \mathrm{mg} / 100 \mathrm{~g}$ of pulp of the fruit (Rahman, 2003) was also evaluated in the bottle gourd fruits which were inoculated with the spore suspension of Alternaria alternata and Colletotrichum gloeosporioides after different periods of incubation from the graph three it was noted that maximum (58.72) degradation of ascorbic acid was after $18^{\text {th }}$ day of incubation followed by $52.36 \%$ after $15^{\text {th }}$ day. Minimum $10.68 \%$ degradation was noted after the $3^{\text {rd }}$ day of incubation among the fruits inoculated with a spore suspension of Alternaria alternata. At the same periods of incubation, fruits inoculated with Colletotrichum gloeosporioides revealed 54.18, 46.62 and 9.54\% degradation of ascorbic acid respectively.

\section{DISCUSSION}

Impact of two phytopathogenic fungi viz., Alternaria alternata and Colletotrichum gloeosporioides inoculated in fruits of bottle gourd on the degradation of sugar, protein and ascorbic acid was evaluated after different periods of incubation.

In the present study, it was noted that all the three nutritional components were degraded and the quantum of degradation directly depended on the types of phytopathogens as well as the incubation periods. Minimum degradation of all the above three nutritional components was after the $3^{\text {rd }}$ day of incubation which increases gradually to $58.72 \%$ after the $12^{\text {th }}$ day of incubation.

The above findings are in agreement with Hossain et al., (1999) who reported degradation of the nutritional component in mango by Colletotrichum gloeosporioides, Ponmurugan and Baby (2007) in tea, by Phoma, Srivastva et al., (2011), changes in sugar in Kususm. Chatage and Bhale (2012) in Coccinia indica, Ghad Singh and Mandge (2012) in tomato by Alternaria alternata, Srivastva \& Kumar in Onion \& Capsicum, Embaby and Korkar (2015) in case of guava, Rawat in different commodity, Meena et al., (2017) in tomato, with respect to sugar and protein.

\section{CONCLUSION}

Phytopathogenic fungi are heterotrophs, so they utilize the stored food materials for their own growth. The rate of degradation varied here along with the incubation periods as well with the fungal types. Along with the incubation, there was an increase in the fungal mycelia mass and this increases the demand for carbon, nitrogen, and vitamins. Naturally, the degradation rate would increase. Similarly, the degradation rate was higher in Alternaria alternata than Colletotrichum gloeosporioides because, Alternaria produces mycotoxin as a secondary metabolite that has a phytotoxic effect, so it promoted biochemical changes. This increases its potency for disease development.

\section{ACKNOWLEDGMENT}

The authors are obliged to the Head, University Department of Botany, B.R. Ambedkar Bihar University, Muzaffarpur, for providing Laboratory and Library facilities.

\section{REFERENCES}

Agarwal P. and Agarwal G.P., 1982. Alteration in phenols of papaya fruits infected by Colletotrichum spp. Proc. Indian Natn. Sci. Acad., 3: 422-426.

Aldesuguy H.S. and Baka Z.A.M., 1992. Physiological and biochemical changes in host leaf tissues associated with the growth of two biotrophic fungi growing in Egypt. Phyton, 32(1): 129-142.

Bhale U.N., Kamble S.S. and Ganga Wane L.V., 2010. Biochemical changes in spinach infected with 
Carbendazim resistant Alternaria spinaciae. Indian Phytopathology, 63: 230-231.

Birgeu J.K., 2017. Effects of stages of maturity on the susceptibility of tomato fruits to post harvest fungal pathogens. Int. J. of Plant and Animal Sciences, 5(1): 140-147.

Chatage V.S. and Bhale U.N., 2012. Changes in some biochemical parameters of Coccinia indica wight and Aru fruit after infection of fruit rot. Plant Pathology and Microbiology, 3(3): 1-3.

Embaby E.S.M. and Korkar H.M., 2015. Decay of guava fruit (Psidium guajava L.) quality caused by some mold fungi. Int. J. Agric. Technology, 11(3): 713730 .

Gangawane L.V. and Datar V.V., 1978. Ascorbic acid content of healthy and Alternaria solani infected tomato germplasm. Indian Phytopathology, 31: 237-238.

Ghad Singh P.G. and Mandge S.V., 2012. Nutritional spoilage of tomato and brinjal fruits due to post harvest fungi. Current Botany, 3(4): 10-12.

Hossain M.T., Alam M.Z. and Absar N., 1999. Changes in different nutrients and enzyme contents in mango leaves infected with Colletotrichum gloeosporioides. Indian Phytopath., 52(1): 75-76.

Ismail M.E., Abdel-Monain M.F. and Mostafa Y.M., 2012. Identification and phytopathogenic bacteria associated with soft rot disease of gerasole tuber in Egypt. J. of Bacteriology Research, 4(1): 1-8.

Janave M.T., 2008. Biochemical changes induced due to Staphylococcal infection in spongy alphanso mango (Mangifera indica) fruits. J. Crop. Sci. Biotech, 10: 167-174.

Kedarnath, Solanky K.O., Mahatma M.K., Madhubala and Rakesh M. Swami, 2015. Role of total soluble sugar, phenols and defense related enzymes in relation to banana fruit rot by Lasiodiplodia theobromae (Path. Griff and Manble) during ripening. J. Plant Pathol. Microb., 6(8): 299-305.

Khilare V.C., Kadam K.S. and Gangawane L.V., 2005. Biochemical changes in host by Anreofungin resistant Alternaria tenuis causing fruit rot of grapes. Bioinfolet, 2: 77-80.

Lowry OH., Rose Brough N.J., Farr A.L. and Randall R.J., 1951. Protein measurement with folin phenol reagent. J. Biol. Chem., 193: 265-275.

Mahadevan A. and Sridhar R., 1982. Methods in physiological plant pathology. Shivakami Publication, India.

Meena M., Zehra A., Dubey M.K., Amin M. and Gupta V.K., 2016. Comparative evaluation of biochemical changes in tomato (Lycopersicon esculentum mill) infected by Alternaria alternata and its toxic metabolites. Front Plant Sci., 7: 14081412.

Meena M., Prasad V. and Upadhyay R.S., 2017. Evaluation of biochemical changes in leaves of tomato, infected with Alternaria alternata and its metabolites. Int. J. of Plant Res., 30(1): 1-6.

Muzumdar V.L. and Pathak V.N., 1989. Changes in nutritional value of guava fruits infected by major post harvest pathogens. Plant Foods Hum. Nutr., 39: 311-315.

Ponmurugan P. and Baby U.I., 2007. Morphological, physiological and Biochemical changes in resistant and susceptible cultivars of tea in relation of Phomopsis disease. Plant Pathology Journal, 6(1): 91-94.

Rahman A.S., 2003. Bottle gourd (Lagenaria siceraria) A vegetable for good health. Nat. Prod. Rad., 2: 4952.

Rajmane S.D. and Korekar S.L., 2014. Biochemical changes (Reducing sugar) in different mango and papaya fruits varieties. International J. of Scientific and Res. Publications, 4(3): 1-3.

Rathod G. and Chavan A.M., 2012. Status of biochemical content in papaya (Carica papaya) after postharvest pathogenesis by fungi. Current Botany, 3(3): 28-33.

Rawat S., 2015. Food spoilage: Microorganisms and their prevention. Asian J. of Plant Science and Research, 5(4): 47-56. 
Sawant S.G. and Gawai D.U., 2011. Biochemical changes in banana fruits due to post harvest fungal pathogens. Current Botany, 2: 41-42.

Srivastava A. and Kumar S., 2013. Biochemical changes in post harvested Allium sepa (onion) and Capsicum annum, under influence of pathogens. J. Agric. And Veterinary Sci., 5(4): 18-21.

Srivastva A.K. and Pandey G.K., 2012. Glucose and total sugar content and changes there in the seeds of Schleichera oleosa (Kusum) due to biodeterioration by pathogenic fungi during storage. Int. J. of Recent Trends in Science \& Techn., 3(3): 85-87.

Srivastva M.P. and Tondon R.N., 1966. Effect of Botryodeplodia infection on the vitamin $\mathrm{C}$, content of mango fruits. Current Science, 351: 419-421.

Wagh P.M. and Bhale U.N., 2012. Changes in phenolic contents of Sapota pulp (Achras sapota) due to different isolates of Aspergillus niger. Bioscience Discovery, 3: 263-265. 